\title{
Hypothesising the emerging core characteristics of Vietnam's political economy
}

\author{
Adam Fforde ${ }^{1}$ \\ Adam@aduki.com.au
}

\begin{abstract}
The paper offers an analytical framework for understanding the core drivers of the political economy of the ruling Communist Party in Vietnam, seeing this as driven by the absence of political reform, so that, lacking core authority, the regime does not possess those new powers required by the new conditions of market economy and an increasingly open society. Designed for Soviet totalitarianism, and without popular support, formal political institutions are anachronistic and so limit the range of powers available to the Party. As the regime is thus unable reliably to deploy policy, unless the regime feels threatened politics becomes one of competition over spoils. Thus, if macroeconomic instability actually or potentially threatens the regime, the Politburo gains authority to act and policy has been deployed. Yet popular discontent over corruption, favourable treatment of politicallyconnected businesses, public education, public health and other areas, not seen as regimethreatening, mounts, leading to a disequilibrium, and use of the security forces and increasing violence against popular opposition. Further research is needed to judge the value of the framework.
\end{abstract}

Key words: Vietnam, policy, political economy, Communism, development, corruption

\footnotetext{
${ }^{1}$ Professorial Fellow, Victoria Institute for Strategic Economic Studies, Victoria University; the paper is draws upon ideas, since heavily developed, first presented publicly in a paper presented at the Conference: "Remaking the Vietnamese State: Implications for Viet Nam \& Beyond" August 2008, City University of Hong Kong, organised by Jonathan London. Thanks to participants and reviewers, and also to Joerg Wischermann and Tran Huy Chuong for support and advice. The paper draws heavily upon ideas in Fforde and Homutova, 2017 mimeo (under review).
}

This is the author manuscript accepted for publication and has undergone full peer review but has not been through the copyediting, typesetting, pagination and proofreading process, which may lead to differences between this version and the Version of Record. Please cite this article as doi: 10.1111/apel.12191

This article is protected by copyright. All rights reserved. 


\title{
The emerging core characteristics of Vietnam's political economy
}

\author{
Adam Fforde ${ }^{1}$
}

\begin{abstract}
The paper offers an understanding of the core drivers of the political economy of the ruling Communist Party in Vietnam. In the absence of political reform, the regime does not possess the powers required by the new conditions of a market economy and an increasingly open society. Designed for Soviet totalitarianism, and without popular support or authority, the formal political institutions are anachronistic and so limit the range of powers available to the Party. As the regime is thus unable reliably to deploy policy unless it feels threatened, politics becomes one of competition over spoils. Thus, if macroeconomic instability actually or potentially threatens the regime, the Politburo gains authority to act and policy is deployed. Yet, as popular discontent mounts over corruption, favourable treatment of politically-connected businesses, public education and health, and other areas not seen as regime-threatening, the disequilibrium leads to use of the security forces and increasing violence against popular opposition.
\end{abstract}

\section{Introduction}

This paper is part of a wider research project on the economic and political history of Vietnam since the early 1990s that draws upon earlier work (e.g. de Vylder and Fforde 1996; Fforde 2007). The motivation is to explore a potentially valuable hypothesis for this history, which is the idea that, for reasons discussed in the paper, the political economy of Vietnam's emergent capitalism is one that (perhaps for the moment) finds it unusually hard to create and preserve what is called here 'state development rents' (SDRs). Authoritative pro-growth use of state power appears only to happen when regime adherents feel that the regime is threatened, but not generally otherwise. The methodology used draws upon a large volume of existing work to explore, somewhat inductively, this hypothesis and its potential value. It does not seek to test the hypothesis exhaustively and leaves this task for future work.

The basic analytical framework proposed analyses the political economy of the ruling Vietnamese Communist Party (VCP) as a formally unreformed Party still reliant upon Soviet institutions as they were in the late 1950s as Soviet material and technical assistance started (Fforde and Mazyrin forthcoming). Reflecting the political restructuring that took place after the removal of Beria in the aftermath of Stalin's death, thus ensuring that the Soviet Union would not become an institutionalised dictatorship, Khrushchev's politics can be read as founding post-Stalinism on two principles that appear to be strong elements of how the VCP still runs itself: first, that sovereignty lies with the Party (not the Dictator); and second, that

\footnotetext{
${ }^{1}$ Professorial Fellow, Victoria Institute for Strategic Economic Studies, Victoria University; e-mail: Adam@aduki.com.au. The paper draws upon ideas presented at the Conference 'Remaking the Vietnamese State: Implications for Viet Nam and Beyond', August 2008, City University of Hong Kong. Thanks to participants at the conference and reviewers, and also to Joerg Wischermann and Tran Huy Chuong for support and advice.
} 
the Party's internal structures contain various checks and balances to prevent a return to an excessive concentration of power (Taubman 2003; McAuley 1977; Brown 1997). The paper discusses some evidence for and against the framework.

Both before and after the 1986 VIth 'doi moi' Party Congress, powerful commercial forces unleashed in the state sector found they could play to these principles. Initially given added impetus by the sharp fall in resources supplied to them through the planning system as Chinese and most Western aid was lost in the late 1970s, these commercial forces were initially supported by strong peak Party support at the $6^{\text {th }}$ Plenum of 1979 as a 'regime survival' issue that supported massive disregard for Communist doctrine of the time. Written into policy in early 1981 by Decree 25-CP, the second post-Stalinist principle now came into play as State Owned Enterprise (SOE) managers and their supporters - a core element of the Party/State guaranteed representation in committees as Party insiders - could argue for protection of their commercial activities (and oil the wheels of debate by pay-offs) (Fforde $2007,2014)$. Thus, whilst formal policy initially sought to curb these activities, at a time when the large Soviet aid program was driving fast economic growth and feeding the centralplanning apparat, the stance was reversed in early 1986 before the VIth Congress (Fforde 2007, Chapter 7). The core of the Party/State's resource-creating activities cannot be understood separate from what happened in the Soviet Union after the death of Beria. Without such checks and balances, 'fence-breaking' activities under Stalin would have been deemed anti-socialist.

In the closing years of the 1980s Vietnam experienced hyperinflation; and it appears that this etched into the minds of many VCP leaders the belief that macroeconomic instability was regime-threatening. The debacle of the Price-Wage-Money reforms of 1985 had seen the dismissal of Deputy-Premier Tran Phuong and Politburo Member To Huu. The tax base collapsed and by the end of the decade the Leninist Mass Organisations such as the Farmers and Women's Unions were being threatened with having to become self-funded.

Two incidents illustrate the strength of this belief: the preservation of macroeconomic stability in $1997 ;^{2}$ and its restoration in the early 2010s. In 1997, state commercial banks were over-extended in their Letters of Credit commitments and were rescued by Politburoapproved actions by the State Bank at a cost estimated at 3 per cent of GDP (Leung and Doanh 1998). Other evidence at this time points to more rather than less coherence in the use of state power. Following the analytical framework suggested here, this suggests that fears of regime survival had greater political significance at the time than later. ${ }^{3}$

Despite this hiccup, from around 1993 to 2007 Vietnam experienced rather fast GDP growth, macroeconomic stability, and a high and rising share of the state sector in GDP. For conventional economic analyses, this outcome is somewhat unexpected and perhaps even paradoxical; for the assumption would tend to be that in a globalised economy political links with SOEs would mean that they would be inefficient and in receipt of large volumes of state support, leading to slow growth and macroeconomic instability. The analytical framework suggested here explains this outcome through the idea that - in part drawing upon the Soviet legacy and the fear that macroeconomic instability could be regime-threatening-limits were placed upon the politically-acceptable levels of state support. This could be called a 'hard budget constraint' at the macro level and a 'soft budget constraint' at the micro level.

\footnotetext{
${ }^{2}$ I thank an anonymous referee for bringing the 1997 experience to my attention.

${ }^{3}$ See the analysis and required actions reported to have been presented at the national conference of State Bank managers in January 1998 (Tuoi Tre (Youth) 17/2/98:11).
} 
The period after 2007 is intriguing, for, whilst for some years SOEs appear to have secured far greater political influence-leading to great waste and macroeconomic instability - this influence was sweated out of the system rather quickly and stability was re-established. At the 2016 XIIth Party Congress the political career of the Premier, who had received SOE support, was ended. I return to this point later, but it is clear that this 'non-Party' threat (of a replacement of Party leadership by state leadership), which violated the principle of checks and balances within the Party structures, would have been anathema to the post-Stalinist Soviet reformers led by Khrushchev. ${ }^{4}$

As a developing country situated in a region with many examples of rapid growth, and with abundant policy advice from donors and academics, in the 1990s the Party was expected to exert the authority it was believed to have to devise and implement new policies suited to a market economy with an increasingly open society-very different conditions from those of the Soviet Union, the origin of its political institutions. Recovery of the tax base and a replacement of lost Soviet bloc aid in the early 1990s offered resources that could finance policy initiatives to secure growth: growth of a style that would suit the country. But, with political institutions unreformed, it is hypothesised that the forms of power required to manage use of these resources developmentally were lacking. Clearly, the regime had not reacquired the credibility that could come from its acceptance by the population. Increasingly, failure to govern - to devise and implement suitable policy-would lead to popular discontent and recourse to those powers that the unreformed political institutions did confer: use of the security apparatus and extension of the Party/State apparat deeper into the population. ${ }^{5}$

With this tentative characterisation of the basic political economy of the Party, I now turn to look at the associated question of rent-creation. If the 'fence-breaking' of the early 1980s and earlier was growth-enhancing, as part of a commercial renaissance (Fforde 2007), this was mainly because its relationship with central-planning was parasitic - eventually harmful to the host - rather than the symbiotic relationship between production for the market and the plan that was accepted by Soviet thinkers (for example, the private plots in collectivised agriculture and the Kosygin reforms of the 1970s). But success in preserving state resources from such 'sticky fingers' should have had quite a different political meaning if, as the regime sought and as donors encouraged it to do, legitimacy from economic growth of a type that led the population to see it, more often than not, as governing well.

\section{How to write the economic history of Vietnam?}

\section{Rents}

Rent-creation and rent-seeking are important elements of any political economy, even if only through consideration of them we can examine the political conditions needed to maintain them within limits. The analytical framework suggested here implies that absence of authority would mean that local interests within the Party/State would be insubordinate,

\footnotetext{
${ }^{4}$ Historically, Khrushchev fought off a Politburo group hostile to his position that outnumbered him in the Politburo by appealing to the Central Committee and labelling them 'anti-Party' (Taubman 2003). Formally, Party sovereignty appears to be defined as 'the Politburo subject to review by the Central Committee'. ${ }^{5}$ Thus the valuable study by Angie Tran (2013) on labour relations shows that in the 'noughties' workers initially trusted that laws they viewed as supporting them and their rights would be followed, and concluded from bitter experience that they would not be. The regime responded by constructing detailed structures to penetrate worker life (such as spies in their dormitories): a security response. It took pressure from the US a decade later to secure Party commitment to free trade unions, the reality of which is yet to be seen at the time of writing.
} 
policy implementation would not normally be ensured, and only when there was belief that the regime was threatened would 'the Politburo act'. This outcome implies that policy as such would carry little weight; policy would have attached to it the weight of central political authority only under the unusual conditions of there being a perceived threat to the regime. To repeat, the implied disequilibrium is that, if as time passes the associated 'failure to govern' is perceived by the population as increasingly obvious and intolerable, as in any political community it is not simply those in power who can act politically to explore new forms of power and acquire authority in so doing. ${ }^{6}$

By the 2010s it was clear that this was the case:

According to Clause 5 of the Government Prices Order: The state implements policies and measures as needed to act on supply-demand relationships so as to stabilize market prices for those commodities and services that are important or crucial, to control inflation, to stabilise socio-economic conditions, to defend the rights and legal interests of organisations and individuals in production and business, of consumers and of the state, contributing to stimulating investment and development. (Petrolimex ${ }^{7} 2013$ - my translation)

In the opinion of the Military Petroleum Corporation, ${ }^{8}$ at the present time establishment of a [price stabilisation] fund would not stabilize prices. On the contrary, it would create gains for certain businesses who would use it to reduce their borrowings. In turn that would create competitive advantages, leading to monopoly, and reduced competition in the petroleum business. (Dñ th£o Online, 2015 - my translation)

It may appear that the two quotations above reflect familiar policy differences, manifest in political competition, but my analytical framework suggests otherwise. Instead, they reflect pessimism about the implementability of policy. This issue has been discussed in the literature. Compare, for example, Leung and Gainsborough:

Leung sees lack of policy implementation as mainly a political matter:

... questions are being raised about the political will of the [Vietnamese] government to make the needed structural reforms in such a way that benefit the economy rather than powerful insiders. (Leung 2015:8)

By contrast, focussing on the 'can't' rather than the 'won't', in 2007 Martin Gainsborough published a seminal analysis of Vietnamese politics, based upon close-up observation of political behaviour in the run-up to the 2006 Xth Congress of the Vietnamese Communist Party (VCP). He concluded that:

... politicians in Vietnam generally do not distinguish themselves from each other on policy lines, although struggles for control over resources are sometimes dressed up in policy terms (Gainsborough 2007:20).

In sharp contrast, but rather earlier, the late Melanie Beresford, in analysing the situation in Vietnam in the early 1990s, argued that the Party or State was responding politically, with policy reforms, to the important interest groups within Vietnam, including the peasantry.

\footnotetext{
${ }^{6}$ Examples can be found, such as in informal farmers' groups (Fforde 2008), labour organisations (Tran 2013), and village level elections (Fforde 2011). Unlike the early 1980s, however, such examples are not part of official discussions (SOE experiences with commercialisation were widely reported for good or bad in the early 1980s in the official press, see Fforde 2007).

${ }^{7}$ PETROLIMEX is a large state conglomerate; details can be found at http://petrolimex.com.vn/en-us.html

${ }^{8}$ Details of this large state conglomerate, MIPECORP, can be found at http://mipecorp.com.vn/vi/\#/en/. MINECORP and PETROLIMEX are both under the 'central business bloc (khôi)' of the Vietnamese Communist Party (Fforde 2014, Appendix 1). For an earlier discussion of rents in the Vietnamese political economy of transition, see Fforde (2010).
} 
Beresford (1993) places centrally the agency of the VCP, seeing it as responding to problems in the rural areas, with resource extraction failing as farm output stagnated, and also because industrialisation was in jeopardy. Her analysis of change at this time centres upon deployment of a coherent series of policy shifts (but see works already cited such as Le Duc Thuy 1993).

However, five years later, Beresford (1997) placed the state rather than the VCP as the prime agent of development, playing a necessary role as the mediator between evolving social interests, with policy shifting accordingly. Her point is that the changing situation was posing new political challenges to which the ruling VCP was responding in coherent policy terms. By 1998, however, the picture was causing her and a co-author concern:

Restructuring and reorganisation of the trade unions have lagged somewhat behind economic practice, while their direction of change is not entirely clear. On the one hand the party-state has not abandoned its paternalistic attitude to workers and has been particularly supportive of workers' in foreign-invested enterprises. On the other hand, the attempt to separate the trade unions from their management function has not met with much success. Not only do old habits within the VGCL die hard, but the Party as a whole seemed unclear in 1997 about how far to release the unions from its grip (Beresford and Nyland 1998:77).

These concerns mounted, and, in what is a clear trend to gathering pessimism about the Party as a progressive force, some years later she was arguing that the state lacked adequate power; and so her view converged towards that of Gainsborough:

... in the case of SEs [State Enterprises], the state's inability, especially under donor pressure, to provide crucial investment support to the SEs meant that foreign investors and the domestic non-state sector began to dominate the economic landscape. While state-led development remains feasible, it requires a clear and more authoritative industry policy; otherwise, the balance of interventionism could eventually tip towards cronyism (Beresford 2008:221).

The question though, is why the state is 'unable' to carry out policy - putting to one side her attempt to blame donor pressure? Here also she addresses political issues, arguing for the need for legitimacy derived from empowerment of the population:

Socialism is not simply a question of technical solutions to the provision of infrastructure, education, etc, or of providing a social safety net. It is mainly a question of empowerment. (Beresford 2008:241)

This brings us back to the question of how the Party could have secured the new powers needed for it to be able to implement policy under the new conditions of a market economy and an increasingly 'open' society. Beresford can be read as concluding that the changing economic base had by the mid-noughties fundamentally eroded the political base of the ruling VCP in the state sector. The relative autonomy of the state, had, by the middle of the noughties ceased to be occupied by social forces, in her terms 'progressive', though she puts it diplomatically. This conclusion supports the analytical framework of this paper, though not explicitly: as the state sector had become increasingly commercialised through the 1980s, driving economic recovery in the early 1990s, it was no longer reliably part of the set of interlocking institutions that underpinned post-Beria Soviet Communism; its power counterbalanced in Party committees by other 'blocs' such as the Mass Organisations, State Organs, security forces, and the Party itself. The genie was threatening to come out of the bottle. Having shown itself parasitic in its relationship to central-planning in the 1980s, its most politically powerful elements could now threaten the regime itself, moving to a political restructuring where state power would focus upon support of 'fat cats'. 
Also writing from a left position, but unlike Beresford deeply sceptical from the start about the politics of state socialism, Greenfield (1993) argues that:

Dismantling the socialist project is central to the agenda of the new policy orthodoxy in Vietnam (p.203)

As is:

the legitimation of the rise of military-owned fractions of capital, and a group of powerful state conglomerates that will differ little from the bureaucratic bourgeoisie which prospered under the authoritarian capitalist regime in the South before 1975 (Greenfield 1993:204).

Such well-informed analyses, coming from a Leftist political direction, suggest that between the early 1990s and the mid noughties there was a profound change. In the early stages of the market economy, and before the powers of the Soviet system had become too anachronistic, the VCP initially had significant relative autonomy. For Beresford, the Party had agency in leading changes that introduced the market economy and then mediated between emerging interests; and, for Greenfield, could deploy 'the exercise of state power against what remains of the socialist project under the rubric of "market reform". (Greenfield 1993:230)

I think this point is exaggerated and debate is needed to clarify what is meant by 'power' and 'policy'; but it is clear that by the mid noughties seeing the different views cited above of the drafters of the Government Prices Order and MINEPCORP as simply an expression of significant policy debate would be wrong. Despite using different analytical perspectives, there appears to be agreement around a major analytical need to explain how (and to what extent, and why) policy, by the mid noughties, in Gainsborough's terms 'did not matter politically'.

\section{Did policy matter, and some implications: societally-driven economic change?}

The failure of an apparently powerful Communist Party to use policy to secure legitimising economic and social change is, for many, counter-intuitive. The analytical framework here hopes to make this failure easier to understand. Thus, it appears obvious to some that a political organisation that presided over the defeat of the French and the American presences, and remained in power as central-planning was replaced by a market economy and its main international patron and source of development aid, the Soviet Union, collapsed, would find management of a market economy a relatively trivial task. In the opening-up of Vietnam to foreign investment in the early 1990s, much was also made of the population's high levels of education, application, and natural proclivities to engage in markets. Wood (1989), reporting on macroeconomic policy measures taken in the late 1980s to curb hyperinflation, frames his analysis in terms of a ruling VCP deploying policy to meet objectives; although he concludes that 'of course it is impossible to know how the economic situation in Vietnam is going to evolve after this initial phase of policy transformation' (p.568). However, whilst de Vylder and Fforde (1996) analyses the shift from plan to market in the 1980s as a largely commercially-driven process, Fforde (2004:121) talks about 'the road to ungovernability'.

Even if not well understood, the failure is now widely accepted. Scholars like Leung argue that the Party 'won't'; here I argue that it 'can't'. The truth is probably somewhere in the middle - after all, we lack good debate about how 'policy' should be understood. Yet whilst the analyses and the possible solutions differ, the diagnosis is the same. Official donors place major question marks over the ability of the country to easily transition through the middle income status reached in the late 2000s. The rapid economic growth of the 1990s and steep reductions in poverty, like the transition from 'plan to market' of the $1980 \mathrm{~s}$, is more readily seen as 'something that happened' rather than the outcome of focussed policy, though debates 
remain. The task of transition through middle income status is linked by donors to the ability to shift from an 'easy' growth pattern that may rely relatively easily upon market forces to a pattern where significant and sustained increases in labour productivity requires an active state - to secure production of public goods such as education, health, infrastructure (especially in urban areas) and institutions that push down transactions costs, such as reliably enforceable contracts, curbs on corruption and competent public servants. This economic infrastructure is widely accepted to be lacking. A generation after the collapse of the Soviet Union the consensus amongst donors and analysts seems to be that such core tasks of government, the responsibility of the ruling VCP, have not been solved. The analytical framework here argues that this is not possible without political reform, but specifies that political reform in terms of change that would allow Vietnam's rulers to acquire an authority that would permit implementation of policy under normal conditions (that is, other than when the concern is regime survival).

Thus, the seminal work by Gainsborough already cited, whilst arguing that by the mid-2000s VCP internal politics had little to do with policy and much to do with spoils, also argues that this reflected issues of authority and structure: in his words there was 'always someone who can potentially stand in your way' (p.179). Besides this scholarship, research into the processes by which the VCP state originally came into being leads, perhaps surprisingly, in similar directions. These conclusions tend to change our views of the original drivers of Vietnamese Communism away from ideology and towards a desire to solve the problems of the moment.

\section{Towards a possible resolution: how important is the 'disequilibrium'?}

The analytical framework proposed here does not suggest that normal policy does not matter. Rather it stresses the tensions created by largely unreformed political institutions that are in origin Soviet, and are clearly not 'fit for purpose' in a market economy with an 'open' society. How does this matter? I discuss this mainly in terms of its implications for how we should understand Vietnam, i.e. analytically. I turn now to discuss the issue of domestic sovereignty.

\section{Sovereignty and the causes of change}

The framework implies that Vietnamese capitalism, now the driver of economic change, is mainly driven by societal forces rather than policy. Concerns to ensure regime survival suggest that the Party can act to try to ensure that this continues and that the disequilibrium, the increasing public dissatisfaction - has little political effect. However, policy may be implemented if its objects concur. That is, if no insider groups, in Gainsborough's phrase, 'will block it'.

Put this way, there is no national agency expressed in national policy. In a sense, we are then in a world, where, for example, the focus in Kerkvliet (2005) upon how peasants changed policy misses the point. To re-jig the rhetoric of de Vylder and Fforde (1988): 'the point is not to get prices right, but to make prices matter'; the point is not 'to get policy right, but to make policy matter'. To understand why this does not happen, the key issue is the absence (so long as the regime does not feel threatened) of domestic sovereignty: the existence of some power or authority believed above all:

Sovereignty, as Hinsley argued some time ago, is a political concept:

The concept has been formulated when conditions have been emphasizing the interdependence between the political society and the more precise phenomenon of its government. It has been the source of greatest preoccupation and contention when conditions have been producing 
rapid changes in the scope of government or in the nature of society or in both. It has been resisted or reviled - it could not be overlooked - when conditions, by producing a close integration between society and government or else by producing a gap between society and government, have inclined men to assume that government and community are identical or else to insist that they ought to be. In a word, the origin and history of the concept of sovereignty are closely linked with the nature, the origin and the history of the state. (2, and quoted in Fforde 2013:16)

This argument implies that such a lack of domestic sovereignty, given the presence of a market economy and an increasingly open society that expects to be governed 'as subjects', is striking but a core element of the political economy of the VCP Party/State. Perversely, perhaps, people learn to live without much expectation that there will under normal conditions be coherent implementable policy. As Fforde (2016) pointed out, whilst the strategic slogan of the Party has long been 'modernisation and industrialisation', the economy has not industrialised whilst growing fast; and this does not seem to matter politically, but rather confirming the state of play. ${ }^{9}$

\section{Lack of sovereignty and the issue of SDRs - state development rents}

Given the analytical framework, in matters of economic development we expect and find an inability to manage the deployment of the relative autonomy of the state to the coherent creation and allocation of resources to development. Rather, behind a series of façades, competition amongst groups occupying positions in the Party/State has had, and continues to have, a strong tendency to divert resources away from uses intended by the dominant growth ideology. This is insubordination in the literal sense. The state, as Kleinen (2001) argued some time ago, is a theatre: but a theatre for what play?

Earlier this was 'socialist construction', nowadays it is the 'socialist-oriented market economy'. In a market economy, attempts at SDR-creation through the tax system, through interference in markets, or through state banks exhibit stable patterns, in that various processes divert such resources into areas that serve private rather than systemic interests. Political competition erodes the advantage sought for implantation of the growth ideology for which the SDRs were created. ${ }^{10}$ This mattered far less in the 1990s than now, when transition through middle income status argues for public goods production, reduction in corruption, and suitable institutions, yet, without regime survival as a driver, insubordination continues.

\section{Economic analyses: what we can learn from economists' data and analyses?}

Under such conditions, economic analyses that seek to explain change in terms of policy will throw up useful results, illuminating the value of the analytical framework.

The nature of competition within the VCP, viewed systemically, creates a situation where, as Gainsborough put it, there are - usually - no barriers to protect such gains or advantages from being privatised. ${ }^{11}$ Unless there is a perceived threat to the regime, the 'relative autonomy of the state' cannot be deployed in such directions, leading instead to reliance upon

\footnotetext{
${ }^{9}$ Huy Duc $(2012,2013)$ provides ample evidence for the relative under-importance of ideology compared with personal opportunities amongst VCP adherents.

${ }^{10}$ See Fforde (2014:24-5) for indicators of the unwillingness of the VCP in the early 1980s to shift SOEs to where - according to the then Soviet-inspired growth ideology — they should be, as part of a process of 'rationalisation'.

${ }^{11}$ In another language, the SDRs are 'switched' from one intended purpose to another (Fforde 2002:205): 'the use of social networks to switch the form of intervention (i.e. rent creation) to maintain advantage as the economic system changes'.
} 
hegemonic power, above all the security forces. What, then, can this imply for rent creation and rent seeking?

A useful definition of a rent is 'a gain or advantage that cannot be competed away' (Levy 1995:96). This definition is usually intended to refer to gains such as land rents, due to better quality land, or advantages due to tariffs or import quotas, or powerful trade unions, where state power (including possible collusion with organised labour) preserves them. But this definition is also illuminating when considering the fate of economic resources at the disposal of, and created by, state power, such as tax revenues and access to state bank credits, which purportedly exist to secure legitimising patterns of state activity, including the generation of public health, education, and urban infrastructure. These are the already-mentioned SDRs. If, however, political competition allows private expropriation of these resources, in effect they cannot be preserved as SDRs, unlike a rent that 'cannot be competed away', and these patterns of state activity suffer. ${ }^{12}$ In that case, the inability to preserve SDRs ostensibly created to facilitate legitimising growth is what needs to be explained.

By the mid-2000s resources had been mobilised that could have been used for such investments; but this potential was dissipated when, as the analytical framework expects, political competition treated them not as SDRs but as spoils. This change explains one aspect of the sharp increase in the ICOR, the Incremental Capital-Output Ratio, i.e. the increase in capital (net investment) required to produce increased output (Berliner et al 2013; Tran Tho Dat et al 2005; Bui Trinh et al 2012). The issue may not primarily be one of inefficiency, but of the diversion of SDRs from their intended purposes; in other words, much of the increase in recorded investment is actually corrupt transfer payments: what is recorded as investment is, in part, generating corrupt incomes. We recall that trend GDP growth rates have remained rather high (though just how high is clearly not accurately measured; indicators such as power consumption and the dynamism of the labour market suggest rather fast growth). Thus, to understand corruption we need to consider it as a transfer to factor incomes rather than a loss to consumption. The analytical framework suggested here then starts to open up a number of very interesting economic puzzles.

The rapid rise within factor incomes of the return to capital can be seen from Table 1. First, while the private sector is by the late 1990s generating a higher operating surplus as a share of total factor income than the state sector, it paid a lower share of total factor income in taxes.

A second point is the treatment of depreciation in SOEs, which had been the subject of considerable contestation through the early 1990s (Fforde 2004 and 2007). To a large degree, these flows returned to being treated as belonging to the state (not the SOE); which suggests that the greatest degree of murkiness within Vietnam's NIA is in the treatment of factor incomes within the state sector (Hoang 2004). This outcome is not surprising as formal ownership has been criticised for being extremely unclear. On the one hand, in the late $2000 \mathrm{~s}$ a Vietnamese study argued that, despite the existence of state structures such as the Ministry of Finance, which is charged with the responsibility of knowing what is going on in SOEs, the relevant data was unavailable. ${ }^{13}$ On the other hand, while many SOEs were made part of conglomerates of various forms in the $1990 \mathrm{~s}$ — such as the T-p oàn-even by the mid-2000s

\footnotetext{
${ }^{12}$ A very early example was the Price Stabilisation Fund set up in the early 1990s to regulate agricultural prices. It proved impossible to prevent politically-supported interests from suborning the way the fund was used and diverting its resources away from the policy goals. There remains strong opposition to such measures.

${ }^{13}$ See Study Team (2009) and the discussion in Fforde (2009).
} 
whether or not those forms were legal entities was not clear; nor were their powers over their members. ${ }^{14}$

A third point relates to the level and meaning of corrupt payments. Recent seminal work that links separate datasets suggests that Vietnamese SMEs pay levels of 'informal' payments that are about the same as their recorded profits. Nguyen et al (2016) argues that, at the level of the firm, such payments are simply paying for the right to do business; and that they have no effect upon how well the business performs:

Results (Table 5) show that from 2009 to 2011, each firm in the sample paid on average from 460 to 600 million VND in informal costs per year (between USD 20,000 to USD 30,000), yet still made 512 to 646 million VND in profit before tax each year (between USD 24,000 and 30,000). The informal payments were equivalent to $78 \%$ - 107\% of the firm's PBT (Profits Before Tax) ... to make 100,000 VND in profit, a firm has to pay between 70,000 and 100,000 VND in informal cost (Nguyen et al. 2016: 9). ${ }^{15}$

Given such payments, economic analysis would suggest the following questions:

- First, treated as a flow, over time they must lead to a considerable stock of assets (of the same order of magnitude as the value of the SME sector). How are these assets held?

- Second, given their order of magnitude, arguments about transactions costs would suggest that collection of such payments would have to be organised. How?

- Third, through what intermediation channels do the funds find profitable investments?

Informal discussion in Ho Chi Minh city shortly after the article was published suggested that local officials indeed usually formed 'funds' ('quy') to manage collection; that the intermediation channels were primarily the banks; and that these funds were often reinvested in SMEs. In that the reinvestment would likely have been on strict commercial grounds, this implies that the dynamism of the Vietnamese SME sector may owe much to these processes, not only in that their 'virtual owners' reinvest in the sector but also that one of the forces pushing for restoration of macroeconomic stability in the early 2010s was precisely these corrupt officials, keen to protect their investments.

\section{$<<$ Table 1 about here $>>$}

This narrative requires further research; but the questions read into the data above are driven by the analytical framework here. Vietnam is not in the main a 'crony capitalism' regime, but a one-Party Communist regime whose unreformed political institutions reflect their Soviet origins, where authoritative power can be deployed to ensure regime survival but cannot be used to implement policy because they lack the powers to do so.

Much existing analysis can then usefully be re-examined. For example, standard accounts of countries that, like Vietnam, experience high levels of corruption tend to assume that because there is corruption, political connections are valuable, as the political economy creates rents for some; and so the key issue is political connection. Indeed, Pincus (2015:42) argues that

\footnotetext{
${ }^{14}$ See Fforde (2014:1), quoting Tran Tien Cuong (2007): 'It is hard to establish general standards to say whether a group of businesses is or is not a tap doan ... Furthermore, a tap doan is not a legal entity, it does not have juridical status. This is because the Enterprise Law, and market custom, sees it as a group of companies or cooperation between various independent companies that are legally independent yet have some mutual influence between the mother company and the child or linked companies'.

${ }^{15}$ The exchange rates used are those of the original.
} 
the state has been in effect 'marketized'. The power of vested interests, it is then argued, requires strong political commitment to push through structural reforms; without this we find analysts such as Leung arguing, as above, that the regime 'won't' do what it should. The research reported in Nguyen et al. (2016) contradicts this view, as it says that SMEs' informal payments, whilst large, are more or less the same for all and have not much effect upon subsequent performance.

Other evidence also suggests that political connections are not normally linked to preferential access to resources; and that failure to create sustainable patterns of rent-creation and to limit expropriation of SDRs is a characteristic of Vietnam's political economy. There is evidence to support both this view and the more conventional one that corrupt payments should confer some advantage over those who do not make such payments. ${ }^{16}$

Based upon a large dataset, Malesky and Taussig (2008) examine the value to businesses of political connections. Their belief is that such connections exist and are harmful to economic performance; and they cite a range of studies to support these views. Yet their empirics suggest a different interpretation. They use a set of proxies that permit quantification of their notion of political connections and conclude that:

[politically] [c]onnected firms are actually not very different from the rest of the private sector. They have very similar investment and profit levels and on average have seen similar levels of expansion over the past year. Connected firms have slightly larger employment, but not much (Malesky and Taussig 2008:15).

Their data permits them to gauge the value of political connections to businesses, and they conclude:

The most robust finding from the model is that personal connections to the government matter a great deal. . . While a firm with no connections has a $48 \%$ probability of receiving a loan, a firm with one connection to the provincial government has a 52\% probability and those with two or three connections have 55\% and 59\% probabilities of receiving loans respectively (Malesky and Taussig 2008:20).

These, however, are extremely low levels of benefit. Moreover, they are gross benefits and, compared with the costs of resources that likely flow from businesses to those helping them obtain loans, these numbers are interesting for what they say about the value of politicians to businesses, and vice versa. From a political point of view, I conclude, that the data says that connections are simply not that valuable. Gaining an increased chance of a loan by a few percentage points is not likely worth the costs incurred. It is not, therefore, so strange that Malesky and Taussig conclude that the main business game is elsewhere:

The most profitable private firms in Vietnam are not attempting to access bank loans at all; they are content to operate primarily out of retained earnings (Malesky and Taussig 2008:29).

If this data suggests that political links appear not to be valuable for businesses, we can ask about ideologically-favoured elements of the working class. Consider Nguyen (2006), who examines data suggestive of the lack of politically-driven earnings differentials between the

\footnotetext{
${ }^{16}$ I thank a reviewer for pointing me to the study by Markussen and Tarp (2014), which argues that for rural households, political connections do matter. However, the discussion of the analysis of Malesky and Taussig (2008) suggests that the interpretation of the research results, especially when juxtaposed with the picture presented by Nguyen et al. (2016), requires care: it is normal to assume that corrupt payments confer particular rather than general benefits, rather than, as Nguyen et al. (2016) suggest, acting as a combination of a right to operate and a return to a virtual investor. For a discussion of the idea that SOEs in Vietnam can be viewed as 'virtual share companies' see Fforde (2004).
} 
private and state sectors. One would expect the latter to be favoured, given the sectoral links to the VCP. However, that study concludes:

For men, public workers are paid lower than private workers. For women, public administration wages are lower than private wages. However, SOE wages are higher than private wages for women. The wage differential is mostly due to the differential in characteristics in which public workers have richer characteristics than private workers. In these worker characteristics, education is the most important element accounting for wage differentials (Nguyen 2006:2).

Again, it appears that politics has not succeeded in creating groups that appear to be doing better than others. These studies are valuable, but not conclusive, and more research is needed. They suggest that my analytical framework allows me to see that an emerging characteristic of the Vietnamese political economy is the absence of coherent links between the political and the economic in areas where this would have been thought to be important. Just as lack of political reform implies the unavailability of powers to ensure that policy can be implemented, so we also find, for SMEs and state workers, an absence of coherent political strategies to favour some at the expense of others.

Under such conditions economic forces will be relatively powerful, and neither guided nor regulated much by government. This picture is confirmed by a range of economic studies that have examined the source of economic growth in Vietnam in quantitative terms. What is interesting about these studies is the strong market dynamics revealed and the relative inability to attribute change to policy. ${ }^{17}$ See, for example, Pham et al (2008:33) and Tran and Giesecke (2008). The story in both studies is one where change is not attributed to policy. ${ }^{18}$ This fits with the argument that the state has not been able to secure changes in the pattern of economic growth to suit national development strategy, despite what its slogans say it has been doing.

This conclusion is supported by the observation, implied by Beresford (2008), that it is the absence of an ideologically coherent strategy to boost economic growth that is striking, reflected in the rather slow growth of the industrial sector, where SOEs were concentrated. So we see the playing-out of economic logic largely uninfluenced by state action. Once middle income status was attained in the late 2000 s, however, public goods production and other tasks of the state became important for sustained fast growth as part of a regime-legitimising ideology (Pincus 2015; Berliner et al 2013).

\section{The 'Vietnam paradox'?}

As the previous section shows, the analytical framework suggested illuminates the process of economic change and allows for a more nuanced assessment of issues such as corruption. In this section I use the framework to look at the politics of macroeconomic instability.

From 1993 to 2007 we observe a relative absence of macroeconomic distortions and a relatively level playing-field in terms of access to rents - especially cheap credit, foreign currency, and state-subsidised labour. This absence was striking up to around 2007. I call it the 'Vietnam paradox'—-macroeconomic stability despite the large state sector. Like all supposed paradoxes, I am sure this combination can be found elsewhere. But my focus here

\footnotetext{
${ }^{17}$ Recall that, despite the Party development slogan of 'modernisation and industrialisation', we find a pattern of services development not industrialisation (Fforde 2016).

${ }^{18}$ I stress that I am not arguing that policy is always unimportant. As in the analysis of the policy shifts of the early 1980s, awareness of underlying economic forces allows for a far better assessment of policy impact (Fforde 2007, 2014).
} 
is on when some large economic forces — state holding companies ( $\mathrm{T}-\mathrm{p}$ oàn $)$ —made a push to secure creation of, and access, to rents.

Pham et al (2008:31) shows the relative importance of the so-called state sector very clearly. ${ }^{19}$ One complication amongst many in interpreting the statistics is that the "non-state sector' includes foreign-invested companies, many of which are joint ventures where the Vietnamese partner is an SOE. But including these would presumably increase the reported share; making the point stronger rather than weaker.

Against this background the macroeconomic instability after 2007 appears consistent with my analytical framework. During the period of macroeconomic stability before 2007, SDRs grew with the creation of a tax-base and state influence over mediated savings and other investable resources. The weakness of the state and its inability to 'do policy' meant that these tended to be syphoned off and sometimes used as capital (the latter point most clearly shown by the data in Nguyen et al. 2016). The inherent disequilibrium was that without acquired authority, the growth of large players within the Party/State - well equipped to secure influencewould almost naturally be led to a political play that would see them seek to secure better access to SDRs, at the cost of other players.

The breakdown of macroeconomic stability in 2007 can then be seen as an attempt to gain access to these resources by large state holding companies; but this macroeconomic instability, itself creating rents that were initially channelled to them, created powerful political opposition. As before, when the regime was threatened, authority was found and the Politburo asserted its sovereignty. This clarifies the point that the regime is Communist, loyal to the core principles of the Khrushchev program post-Beria: the Party is the site of sovereignty and power within it should be managed through checks and balances 'lest we lose our heads'. This manifestation makes it different from crony capitalism; and also rather different from other authoritarian regimes. It copes with its inability to 'do policy' by preserving regime-protecting powers; it is organised and in some sense 'constitutional'. It also means that economic change is far less dependent upon policy and far more dependent upon social and economic forces.

\section{Conclusions}

The paper advances an analytical framework for understanding the political economy of the VCP, ruler of the one-Party Vietnamese state. This framework stresses the lack of authority, under normal conditions, that arises from the lack of political reform; as existing institutions, designed for post-Beria Soviet conditions, must now co-exist with an increasingly 'open' economy. Two principles are identified that are a legacy of Khrushchev's political reconstruction of the Soviet Union in the second half of the 1950s. First, that sovereignty lies with the Party; and second that within the Party there must be checks and balances to prevent the rise of 'a Stalin'. This framing argues that on the one hand normal policy, and the protection of state development resource (SDRs) from appropriation, is unlikely; which explains what is commonly remarked about Vietnam - that policy is not normally implantable. However, the first principle implies that questions of regime survival generate suitable central authority and so power; and the legacy of the late 1980's hyperinflation, and the push from the Premier in the early 2010s, encourage a view that macroeconomic instability is indeed 'regime threatening'.

\footnotetext{
${ }^{19}$ The recorded state share of GDP rises from around $32 \%$ in 1989 to $40 \%$ in 1995 , where it approximately stays until the middle of the noughties, after which it starts to fall, reaching around 32\% by 2013 [GSP 2014: table 9], where it had started.
} 
Further research is needed to assess the value of the framework; and the paper has pointed to where this might occur. The seminal work by Nguyen et al (2016) suggests that the nature of corruption and its various forms, and its variation over time, is intriguing. Equally, the evidence that 'policy does matter as much as one might think', suggests that we need to think through carefully what is meant by policy and how such meanings vary over different contexts. In the language of 'critique', how we use the two terms corruption and policy needs to be 'deconstructed'; in other words, it should be useful to devote resources to 'thinkingthem-through'.

In this sense Vietnam's governance would not usefully be described as 'crony capitalism'. As in the UK in the $18^{\text {th }}$ century, one can argue that there is sufficient domestic sovereignty and its associated political practices and institutions for authoritative sovereign powers to be deployed as required to impose discipline - even if those disciplined have impeccable political connections. Because of its political history and the Soviet connection, Vietnam is different from other authoritarian regimes; although comparative research is needed to think about how and why.

Analysed in this way, the situation clearly contains disequilibria. The obvious potential source of additional political authority is the general population, who are increasingly unhappy with the failure of the Party and its government to govern well, to maintain rapid economic growth in a suitable style. Signs of unrest and popular disdain are mounting, as is the use of the security forces to control them. Yet, if these problems become too large, and are seen by sufficient regime adherents as regime-threatening, the first principle would arguably come into play. It has to be born in mind that for most Vietnamese the market economy offers freedoms and opportunities that are well beyond anything they have experienced; so it is not surprising that they report high levels of support for a market economy. ${ }^{20}$

\footnotetext{
${ }^{20}$ Based on the Pew Global Attitudes Project, Goertzel (2006:4-5) reports the finding that: 'Brazilians are divided in their opinions about the market economy, with $56 \%$ in the Pew survey agreeing that "most people are better off in a free market economy, even though some people are rich and some are poor". Only $26.7 \%$ of the Argentines shared this sentiment in the midst of their economic crisis, as compared to $72.1 \%$ in the United States and a remarkable $95.4 \%$ in Vietnam, $43.6 \%$ in India, $54.2 \%$ in Bolivia and 62.8\% in Venezuela'.
} 


\section{Bibliography}

Beresford, M., 1993. 'The political economy of dismantling the 'bureaucratic centralism and subsidy system' in Vietnam', in K. Hewison et al. (eds), Southeast Asia in the 1990s: Authoritarianism, Democracy, and Capitalism. Allen and Unwin, Sydney.

Beresford, M., 1997. 'Vietnam: the Transition from Central Planning', in G. Rodan et al. (eds), The Political Economy of South-East Asia, Oxford University Press, Oxford.

Beresford, M., 2008, 'Doi Moi in review: the challenges of building market socialism in Vietnam', Journal of Contemporary Asia, 38(2):221-43.

Berliner, T., et al, 2013, Inequality, Poverty Reduction and the Middle-Income Trap in Vietnam, EU and Mekong Economics, Hanoi.

Brown, A., 1997, The Gorbachev Factor, Oxford University Press, Oxford.

Bui Trinh, Kiyoshi Kobayashi, Pham Le Hoa and Nguyen Viet Phong, 2012. 'Vietnamese economic structural change and policy implications', Global Journal of Human Social Sciences, 12(9) Version 1.0.

de Vylder, S, and Fforde, A., 1996. From Plan to Market: The Economic Transition in Vietnam,

Westview, Boulder, CO.

Dñ th£o Online, 2015. 'The need to re-examine the use of price stabilisation funds', http://duthaoonline.quochoi.vn/DuThao/Lists/TT TINLAPPHAP/View_Detail.aspx?ItemID=320 $5 / 5 / 2015$ (translation).

Fforde, A. and Homutova, L., 2017. 'Political authority in Vietnam: Is the Vietnamese Communist Party a paper Leviathan?' Mimeo/under review.

Fforde, A. 1993, 'The political economy of "reform' in Vietnam-some reflections', in B. Ljunggren (ed.) The Challenge of Reform in Indochina, Harvard University Press, Cambridge, MA, pp.293-326.

Fforde, A., 2002. 'Resourcing conservative transition in Vietnam: rent-switching and resource appropriation', Post-Communist Economies, 14(2):203-26.

Fforde, A., 2004. 'Vietnamese state owned enterprises (SOEs) - "Real Property", commercial performance and political economy', Working Paper Series, No. 69, City University of Hong Kong, Hong Kong.

Fforde, A., 2007. Vietnamese State Industry and the Political Economy of Commercial Renaissance: Dragon's Tooth or Curate's Egg? Chandos, Oxford.

Fforde, A., 2010. 'Rethinking the political economy of conservative transition: the case of Vietnam', Journal of Communist Studies and Transition Politics, 26(1):126-46.

Fforde, A., 2011. 'Contemporary Vietnam: political opportunities, conservative formal politics and patterns of radical change', Asian Politics and Policy, 3(2):165-84.

Fforde, A., 2012. 'Vietnam in 2011: questions of domestic sovereignty', Asian Survey, 52(1):176-98.

Fforde, A., 2013. 'Vietnam in 2012: the end of the Party', Asian Survey, 53(1):101-08.

Fforde, A., 2014. 'The historical background to Vietnam's contemporary state enterprise sector: the policy story', Working Paper Series, No. 159, City University of Hong Kong, Hong Kong, http://www.cityu.edu.hk/searc/Resources/Paper/14103017_159\%20-\%20WP\%20$\% 20$ Prof $\% 20$ Fforde.pdf

Fforde, A., 2016, 'Vietnam: economic strategy and economic reality', Journal of Current Southeast Asian Affairs, 35(2):3-30.

Gainsborough, M., 2007. 'From patronage to “outcomes": Vietnam's Communist Party congresses reconsidered', Journal of Vietnamese Studies, 2(1):3-26.

Goertzel, T., 2006. 'Brazilian social attitudes in comparative perspective', a paper prepared for the VIII International Congress of the Brazilian Studies Association, Nashville, TN. http://crab.rutgers.edu/ goertzel

Goscha, C., 2011. Vietnam-Un etat ne de la guerre 1945-1954, Armand Colin, Paris.

Greenfield, G., 1994. 'The emergence of capitalism in Vietnam', Socialist Register.

General Statistical Office (GSO), 2014. Statistical Yearbook, NXB Thong ke, Hanoi.

Hoang Phuong Tan, 2004. Country Paper: Viet Nam, OECD/UNESCAP/ADB Workshop on Assessing and Improving Statistical Quality: Measuring the Non-observed Economy, Bangkok:

UNESCAP, Bangkok. 
Huy Duc, 2012, 2013. The Winning Side, published in EBook form in two volumes and then in hard copy by Amazon http://www.amazon.com/Ben-Thang-Cuoc-Vietnamese-Edition/dp/1484040007

IMF, 2012. 'Understanding Vietnam: macroeconomic conjuncture and growth prospects', Deutsche Bank Access Asia Conference, Singapore.

Kerkvliet, B.J.T., 2005. The Power of Everyday Politics: How Vietnamese Peasants Transformed National Policy, Cornell University Press, London.

Kleinen, J., 2001. 'La comédie de l'Etat-partie. Le Viêt Nam depuis la réunification', Raisons Politiques. Etudes de Pensée Politique, 3:37-54.

Leung, S. and Doanh, L.D., 1998. 'Vietnam', in McLeod, R.S. and Garnaut, R. (eds), East Asia in Crisis, Routledge, London and New York, pp. 120-30.

Leung, S., 2015, 'The Vietnamese economy: seven years after the global financial crisis', Journal of Southeast Asian Economies, 32(1):1-10.

Malesky, E. J. and Taussig, M., 2009. 'Where is credit due? legal institutions, connections, and the efficiency of bank lending in Vietnam', Journal of Law, Economics and Organization, 25(2):53578.

Markussen, T. and Tarp, F., 2014. 'Political connections and land-related investment in rural Vietnam,' Journal of Development Economics, 110:291-302.

Marr, D. G., 1997. Vietnam 1945-The Quest for Power, University of California Press, Berkeley, CA.

Marr, D. G., 2013. Vietnam State, War, and Revolution (1945-1946), University of California Press, Berkeley, CA.

McAuley, M., 1977. Politics and the Soviet Union, Penguin Books, Harmondsworth.

Nguyen Thang Vo, Bao D. Ho, Canh Q. Le, and Hung V. Nguyen, 2016. 'Strategic and transactional costs of corruption: perspectives from Vietnamese firms,' Crime, Law and Social Change, 65(4):35174.

Nguyen van Chinh, et al, 2002. 'The doi moi Vietnamese economy-important analyses and evaluations' Nha xuat ban Thong ke, Hanoi, (translation).

Nguyen, Danh Hoang Long, 2006. Public-private sector wage differentials for males and females in Vietnam, Vietnam-Netherlands project for Master degree on Economics of Development, Hanoi.

Petrolimex, 2013. http://www.petrolimex.com.vn/nd/bao-chi-viet-ve-petrolimex-va-xang-dau/bo-tai-chinhcong-bo-cong-khai-quy-binh-on-gia-xang-dau.html (accessed 7/5/2015).

Pham, Ngoc Quang, Bui Trinh and Thanh Duc Nguyen, 2008. 'Structural change and economic performance of Vietnam 1986-2000: evidence from the three input-output tables', mimeo.

Pincus, J., 2015, 'Why doesn't Vietnam grow faster? State fragmentation and the limits of vent for surplus growth', Journal of Southeast Asian Economies, 32(1):26-51.

Polanyi, K., 1975. The Great Transformation, Octagon Books, New York.

Roman, L., 1998. Institutions in Transition: Vietnamese State Bank Reforms. (http://books.google.com.au/books?id=s7awSSUjWvMC\&pg=PT1\&lpg=PT1\&dq=\%22lisa+roma $\mathrm{n} \% 22+$ institutions + in + transition\&source $=$ web\&ots $=$ ioC4eWg74z\&sig $=i 1 F U q j P s G e S s L P b e C g-$ v8x4gRk0\&hl=en\&sa=X\&oi=book_result\&resnum=6\&ct=result ) Kluwer Academic Publishers.

Sasges, G and Cheshier, S., 2012. Competing legacies: rupture and continuity in Vietnamese political economy, South East Asia Research, 20(1):5-33.

Study Team (2009), Report on the study of the 'Implementation of policies at Groups and General State Companies', National Assembly, Hanoi. (translation).

Taubman, W., 2003. Khrushchev, The Man and His Era, Simon and Schuster, New York.

Tran Hoang Nhi and Giesecke, J.A., 2008. 'Growth and structural change in the Vietnamese economy 1996-2003: a CGE analysis', The Centre of Policy Studies, General Paper No. G-171, Monash University, Melbourne.

Tran Tho Dat et al., 2005. Sources of Vietnam's Economic Growth 1986-2004, National Economics University, Hanoi. (mimeo)

Tran Tien Cuong, 2007. 'Hard to say where is a tap doan', VietBao, (translation).

Tran, Ngoc Angie, 2013. Ties that Bind: Cultural Identity, Class and Law in Vietnam's Labor Resistance, Southeast Asia Program Publications, Cornel University, Ithaca, NY.

Wood, A., 1989. 'Deceleration of inflation with acceleration of price reform: Vietnam's remarkable recent experience', Cambridge Journal of Economics, 13:563-71.

Woodside, A. B., 1976. Community and Revolution in Modern Vietnam, Houghton Mifflin Company, Boston. 
World Bank, 1995. Bureaucrats in Business: The Economics and Politics of Government Ownership, World Bank, Washington, DC.

This article is protected by copyright. All rights reserved. 
Table 1: Total Factor Income Shares, 1999

\begin{tabular}{|c|c|c|c|c|}
\hline (Tr. Dong) & $\begin{array}{l}\text { Compensation } \\
\text { of employees }\end{array}$ & $\begin{array}{l}\text { Tax on } \\
\text { production }\end{array}$ & $\begin{array}{l}\text { Depreciation } \\
\text { of fixed assets }\end{array}$ & $\begin{array}{l}\text { Operating } \\
\text { surplus }\end{array}$ \\
\hline 399.942 & 251.026 & 57.617 & 44.175 & 47.123 \\
\hline 154.927 & 76.025 & 35.52 & 17.409 & 25.972 \\
\hline 3.572 & 2.226 & 0.289 & 0.375 & 0.682 \\
\hline 13.461 & 7.766 & 1.781 & 1.155 & 2.758 \\
\hline 163.481 & 137.437 & 11.174 & 14.738 & 0.132 \\
\hline 15.543 & 7.236 & 2.457 & 1.327 & 4.524 \\
\hline 48.958 & 20.336 & 6.396 & 9.171 & 13.055 \\
\hline
\end{tabular}

TOTAL

State sector

Collective sector

Private sector

Household sector

Mixed

Foreign-invested sector

(\%)

$\begin{array}{rrrrr} & \begin{array}{r}\text { Compensation } \\ \text { of employees }\end{array} & \begin{array}{r}\text { Tax on } \\ \text { production }\end{array} & \begin{array}{r}\text { Depreciation } \\ \text { of fixed assets }\end{array} & \begin{array}{r}\text { Operating } \\ \text { surplus }\end{array} \\ \mathbf{1 0 0 . 0 2} & \mathbf{6 2 . 8 \%} & \mathbf{1 4 . 4 \%} & \mathbf{1 1 . 0 \%} & \mathbf{1 1 . 8 \%} \\ 38.7 \% & 49.1 \% & 22.9 \% & 11.2 \% & 16.8 \% \\ 0.9 \% & 62.3 \% & 8.1 \% & 10.5 \% & 19.1 \% \\ 3.4 \% & 57.7 \% & 13.2 \% & 8.6 \% & 20.5 \% \\ 40.9 \% & 84.1 \% & 6.8 \% & 9.0 \% & 0.1 \% \\ 3.9 \% & 46.6 \% & 15.8 \% & 8.5 \% & 29.1 \% \\ 12.2 \% & 41.5 \% & 13.1 \% & 18.7 \% & 26.7 \%\end{array}$

Source: Nguyen et al.

(2002: 441)

[Note to Production: Please remove the percentage signs against the numbers in the bottom half of this table.

The 100.02 number in the first column of the bottom half of the table should be 100.0. RD]

This article is protected by copyright. All rights reserved. 


\section{University Library}

\section{- M M N E R VA A gateway to Melbourne's research publications}

Minerva Access is the Institutional Repository of The University of Melbourne

Author/s:

Fforde, A

Title:

The emerging core characteristics of Vietnam's political economy

Date:

2017-11-01

Citation:

Fforde, A. (2017). The emerging core characteristics of Vietnam's political economy. ASIANPACIFIC ECONOMIC LITERATURE, 31 (2), pp.45-60. https://doi.org/10.1111/apel.12191.

Persistent Link:

http://hdl.handle.net/11343/293550 